\title{
How Do We Get Them on the Farm? Efforts to Improve Rural Teacher Recruitment and Retention in Arkansas
}

\author{
Robert Maranto \\ University of Arkansas \\ James V. Shuls \\ University of Arkansas
}

Rural schools, particularly high poverty rural schools, often have difficulty hiring and retaining qualified teachers. Here, we discuss three programs the Arkansas Department of Education has used to attract teachers to teacher Geographic Shortage Districts (GSDs) through material incentives. Unfortunately, none of the programs have had much success, perhaps in part since the funding offered was inadequate to attract new teachers to isolated communities. Additionally, we analyze the use of materialistic and non-materialistic incentives on the websites of all school districts designated as GSDs by the Arkansas Department of Education. Few GSDs display nonmaterialistic appeals that might entice individuals to seek out employment in the district, with the notable exception of KIPP Delta, the only charter school on the list, which has much more success recruiting teachers. We end with suggestions for policymakers and school district officials seeking to attract teachers to geographic shortage areas.

Key Words: Teacher shortages, teacher recruitment, teacher bonuses, rural schools, charter schools

As Ingersoll (2003) points out, there is no overall teacher shortage, but shortages do exist for some geographic and subject areas. Math, science, and special education are among the highest need subject areas. Rural and inner city urban districts typically suffer from geographic shortages (McClure \& Reeves, 2004). A highly effective teacher can significantly improve student achievement (Chetty, Friedman, \& Rockoff, 2011; Hanushek, Kain, O'Brien, \& Rivkin, 2005; Rivkin, Hanushek, \& Kain, 2005). In some schools, however, principals worry about simply filling vacancies, not hiring the best teachers. The inability of some rural and urban schools to attract applicants leaves principals in the precarious position of having to hire whoever walks through the door, or failing to offer some courses.

As the baby boom generation prepares to retire, particular market shortages for educators may get worse. Fearing dramatic teacher shortages, both national and state policy-makers have developed programs to increase the number of teachers (Ingersoll, 2002). Further, the numbers of nontraditional paths to teaching, for example, Troops to Teachers, have grown, and indeed nearly a third of new teachers nationally come from outside traditional four-year education programs within colleges and universities (Maranto \& McShane, 2012). Accordingly, states have provided easier pathways for those who seek to change career to receive alternative teacher certification. In addition, state governments often offer incentives to teach in shortage areas. Various states have offered loan forgiveness, bonuses, housing allotments and various other incentives for teaching in a high needs subject area, geographic area, or low-income school (McClure \& Reeves, 2004).

In this article, we summarize the literature on teacher retention and provide analysis of state and local district efforts to recruit teachers to high needs areas. We provide a descriptive overview of three programs initiated with the intent to entice individuals to high needs areas with materialistic incentives. Next, we analyze the websites of the Arkansas Geographic Shortage Districts (GSD) to ascertain their use of materialistic and nonmaterialistic recruitment incentives in the recruitment of teachers. We conclude with suggestions for policy makers and school officials that might attract more and better teachers to these hard to staff areas.

\section{Monetary Incentives for Teacher Retention}

Although widespread, monetary incentives have not proved their ability to attract teachers. For instance, the Massachusetts Signing Bonus Program, which offered a signing bonus of $\$ 20,000$ to attract teachers had little impact in attracting new teachers (Liu, Johnson, \& Peske, 2004). Although it was marketed as an upfront bonus for becoming a teacher, in actuality the payout came in four installments. After the first year the qualifying teachers received $\$ 8,000$; for the subsequent three years they received $\$ 4,000$. Liu, Johnson, and Peske (2004) interviewed 13 participants who indicated the accelerated track to licensure was the biggest draw for them to enter the program. Although the disbursements were designed 
to keep teachers in the field for four years, only five of the 13 teachers interviewed continued teaching long enough to receive all of the bonus money. Although Liu et al.'s study used a very small sample, the fact that teachers were not attracted to remain in teaching for the pay is consistent with other research. Hanushek, Kain, and Rivkin (1999) indicated individuals typically make the decision to teach based on something other than salary. Ballou and Podgursky (1997) suggest that simply raising teacher salaries does not attract teachers and keep them in the field.

As in Massachusetts, retaining teachers poses challenges throughout the United States. Ingersoll (2003) suggested the teacher shortage problem was not due to lack of production of qualified teachers, but rather reflected an inability to retain them. He reported 40 to 50 percent of teachers leave the profession within the first five years of teaching. In a Texas study, Hanushek, Kain, and Rivkin (2004) reported almost 30 percent of teachers change schools within their first three years. Not surprisingly, turnover of teachers is connected to the demographics of the students they teach, including achievement level. Teachers often leave low-paying, low-achieving schools in favor of employment in high-paying, high achieving schools. Critics of Teach for America (TFA) and other non-traditional pathways into the profession often lament that employment of graduates of such programs results in high attrition. However, systematic research finds that the low retention rate reflects the contexts of schools where they teach. TFA, in particular, sends new teachers to high poverty and typically low performing schools. Statistical analyses indicate that turnover of TFA corps members is high, but no higher than for traditionally trained teachers placed at the same schools (Grissom, 2008). High poverty schools often suffer low teacher morale and high teacher attrition no matter where their teachers come from (Payne, 2008). California had results similar to Massachusetts in its Governor's Teaching Fellowship, a $\$ 20,000$ bonus for beginning teachers in low-performing schools. The Governor's Teaching Fellowship increased the probability of a novice teacher entering the workforce at a lowperforming school by $28 \%$. However, teachers who received the fellowship were no more likely to remain in the field for four years than were nonrecipients (Steele, Murnane, \& Willet, 2009).

While the $\$ 20,000$ hiring incentives in Massachusetts and California did not yield favorable results in retaining teachers, North Carolina saw some positive impacts by offering a bonus of only $\$ 1,800$ to teachers of math, science, and special education in high poverty or low performing school districts (Clotfelter, Glennie, Ladd, \& Vigdor, 2006). Though the program was poorly implemented, it did appear to slightly lower teacher attrition. One reason for its small success may be that the North Carolina incentive plan focused on all teachers rather than only on new teachers, where most attrition occurs.

\section{Existing Monetary Incentives in Arkansas}

Arkansas is a relatively rural state which has had considerable difficulty in attracting and retaining teachers, particularly in high poverty rural areas. The Arkansas Department of Education currently tries to attract teachers to high need subject and geographic shortage areas through three programs: High Priority Bonus Incentives, Teacher Housing Development Foundation, and the State Teacher Education Program. These initiatives resulted from Lakeview $v$. Huckabee (2002) ruling. In fact, the Arkansas Teacher Housing Development Act specifically states the Arkansas Supreme Court ruling as the reason for developing the housing program (Ritter, 2009).

In 1992, the Lakeview School District sued the state of Arkansas claiming the education funding system was unconstitutional. Over the next decade, a series of legislative initiatives and court cases ensued. In 2002, the Arkansas Supreme Court affirmed that school funding system in Arkansas was indeed unconstitutional and required a legislative remedy. The legislature responded by developing a new funding formula and passing additional educationrelated legislation in a special legislative session. By 2007, after additional debate and litigation, the Court ruled that the provision of education in state was indeed adequate and thus finally in compliance with the state's constitution. As part of the response to the lawsuit, lawmakers made these provisions to incentivize new teachers into areas of the state that have historically struggled to attract quality teachers (Ritter, 2009).

\section{High Priority Bonus Incentives}

The Arkansas Education Code lists a high priority district as a public school district with less than 1,000 students where $80 \%$ or more of the students are eligible for the National School Lunch Act's free or reduced-price lunches (Arkansas Code $\S$ 6-17-811). Teachers who are new to the profession receive a one-time $\$ 5,000$ bonus upon completion of their first year of teaching in a high priority district. Upon completion of both the second and third year in the district teachers receive $\$ 4,000$. For the next two years of service with the district, teachers are eligible for a $\$ 3,000$ bonus. Each amount increased by $\$ 1,000$ in 2009. In 2007-08, 11 districts were 
designated as high priority districts and 461 teachers received a bonus (Arkansas Department of Education [ADE], 2008). The total payout for the year was $\$ 1,415,952$, a mean of $\$ 3,071$ per teacher in the program.

\section{Teacher Housing Development Foundation}

In 2003, the Legislature passed the Arkansas Teacher Housing Development Act. Under this act, teachers in high priority districts are eligible for housing assistance (Arkansas Education Code $\S 6$-26101). This assistance can come in the form of a conventional mortgage (interest rate not to exceed $6 \%$ ), assistance with a second mortgage of less than $20 \%$ of the home's value (interest rate not to exceed $4 \%$ ), and down payment assistance in the form of loan forgiveness of no more than $10 \%$ of the total cost of the home, or rent reduction. The purchase price of the home must be less than $\$ 100,000$ and it must be located within 30 miles of the high priority district in which the teacher is employed. The reduced rent price must be at least $50 \%$ of fair market value.

To participate in the housing assistance program, teachers must be high-performing and must teach in a high priority district. A high priority district is one that has difficulty recruiting teachers and has less than $50 \%$ of students scoring proficient or advanced on any of the Arkansas benchmark exams. A highperforming teacher must have taught for three years at a district where $50 \%$ of students scored proficient or advanced on all benchmark exams. A teacher can qualify as high performing if he or she has taught at a high priority district and has three letters of recommendation.

\section{State Teacher Education Program}

In 2009, legislators consolidated the Minority Teachers Scholars Program, Minority Masters Fellows Program, and the State Teacher Assistance Resource Program to form the State Teacher Education Program (STEP) (Arkansas Code § 6-81131). STEP is a loan forgiveness program, created to encourage teachers to teach in geographic and subject shortage areas. STEP awards teachers $\$ 3,000$ per year for up to three years for teaching in a subject or geographic shortage area as defined by the Department of Higher Education and Department of Education. Teachers who are classified as in a minority qualify for an additional $\$ 1,000$ for each of the three years. The 2010 subject shortage areas are listed in Table 1. In 2009-10, 188 schools in 54 districts were designated as geographic needs schools (Arkansas Department of Higher Education, 2010)

Table 1

STEP Shortage Areas

\begin{tabular}{ll}
\hline Licensure Areas & Endorsements \\
\hline Mathematics (Secondary, 7-12) & Library Media \\
Mathematics/Science (4-8) & School Counselor \\
English/Language Arts/Social Studies (4-8) & Gifted and Talented \\
Deaf Education & Algebra 1 Middle School \\
& Middle School (5-8) \\
Visually Impaired & (Old Licenses: English (056), Math (111), Social \\
Speech Language Pathologist/Speech Therapist & Studies (159), Science (139) \\
Special Education Instructional Specialist or & \\
$\quad$ (Old Licenses: $\{$ K-12\} Mildly Handicapped, \\
$\quad$ Moderately/Profound Handicapped Severely \\
Emotionally Disturbed) \\
Life/Earth Science (7-12 \\
Physical/Earth Science (7-12) \\
$\quad$ Old Licenses: Biology/Chemistry/Physical \\
$\quad$ Science/Physics)
\end{tabular}


To date, the success these programs have had in attracting new teachers to hard-to-staff districts is not evident. It may be the case that the monetary incentives are simply not enough to attract teachers to these areas, especially when higher salaries can be earned in more desirable locations. Indeed, this may be a problem with merit pay schemes as well, which are often poorly understood and not trusted by teachers, ephemeral, and typically have insufficient rewards to change behavior (Payne, 2008; Ritter, Maranto, \& Buck, 2009). According to data provided by the Arkansas Department of Higher Education, a total of $\$ 1,586,000$ was awarded to teachers in either a subject or geographic shortage area, with a mean payout of $\$ 3,128.21$.
We estimate that $\$ 616,257$ was awarded to geographic shortage districts (GSD), while \$932,207 went to teachers in non-geographic shortage districts (non-GSD). In addition 12 awards were coded as other, accounting for $\$ 37,539$. Presumably, the teachers in non-GSDs taught shortage subjects. One hundred and ninety-seven STEP awards were given to teachers in the 53 GSDs, while 298 teachers received awards in the 192 other districts in the state. This means that, despite having a much smaller average student enrollment, GSDs were two to four times more likely to have teachers receive a STEP award than non-GSDs,. Table 2 shows the number of STEP awards given to geographic shortage districts compared to non-geographic shortage districts in 2010.

Table 2

Comparison of Geographic Shortage Districts (GSDs) with Non-Geographic Shortage Districts (non-GSDs)

\begin{tabular}{|c|c|c|c|c|c|}
\hline & $\begin{array}{l}\text { GSDs } \\
(53)\end{array}$ & $\begin{array}{l}\text { Non-GSDs } \\
192\end{array}$ & $\begin{array}{l}\text { Districts within } \\
3 \text { SD of Avg. } \\
\text { GSD } \\
\text { enrollment } \\
\text { (173) }\end{array}$ & $\begin{array}{l}\text { Districts over } \\
\text { 3SD of Avg. } \\
\text { GSD } \\
\text { enrollment } \\
\text { (19) }\end{array}$ & $\begin{array}{l}\text { State } \\
\text { Average } \\
(245)\end{array}$ \\
\hline $\begin{array}{l}2009 \text { Base } \\
\text { Teacher Salary }\end{array}$ & $\$ 32,245$ & $\$ 33,984$ & $\$ 32,386$ & $\$ 35,839$ & $\$ 33,737$ \\
\hline $\begin{array}{l}2009 \text { Avg. } \\
\text { Teacher Salary }\end{array}$ & $\$ 43,842$ & $\$ 46,428$ & $\$ 43,020$ & $\$ 50,387$ & $\$ 46,056$ \\
\hline Percent FRL & 74 & 54 & 55 & 53 & 57 \\
\hline Percent Minority & 46 & 31 & 19 & 44 & 33 \\
\hline $\begin{array}{l}2009 \text { Avg. } \\
\text { Enrollment }\end{array}$ & 1,253 & 2057 & 1,227 & 9,615 & 1,883 \\
\hline $\begin{array}{l}2010 \text { Total STEP } \\
\text { Awards }\end{array}$ & 197 & 298 & 187 & 111 & 495 \\
\hline $\begin{array}{l}2010 \text { Avg. } \\
\text { STEP Awards } \\
\text { Per District }\end{array}$ & 3.72 & 1.55 & 1.08 & 5.84 & 2. 02 \\
\hline
\end{tabular}

In Arkansas, a statute forces consolidation or closure of districts with enrollments below 350. This creates a positively skewed distribution of district enrollment. As can be seen in Table 2 (data from 2010), GSDs have much smaller average student enrollment than non-GSDs. To make a more accurate comparison of districts, we removed from Table 2, the outlier districts with extremely large student populations, that is, three standard deviations larger than the average GSD (19 in total). GSDs are 3.4 times more likely to have a STEP awarded to one of their teachers than similarly-sized non- GSD districts. Teachers in GSDs are much more likely to receive loan forgiveness from the state than are teachers from similarly sized non GSDs . Notice, however, the 19 non-GSDs with enrollment numbers three standard deviations larger than the GSDs are more likely to have more awards at the district level. This can be explained by the number of teachers working in each group; the large districts have approximately 2.4 times as many teachers as the 53 GSDs. It is also likely the large districts possess administrative resources to help teachers with paperwork. By all accounts, it seems teachers in 
GSDs are awarded loan forgiveness more frequently than teachers in other districts; however, \$347,231 was awarded to teachers in large non-GSDs. In light of the fact that these teachers earn more money on average (approximately $\$ 6,500$ more) than those employed in GSDs, such moneys may be more effective if allocated to areas of greater need .

Whether or not the STEP monies are awarded judiciously is beyond the scope of this article. A more important issue is the influence the awards have on recruiting and retaining teachers in high needs regions of the state. This deserves further exploration in additional research.

\section{Website Recruitment}

In addition to state-wide programs designed to attract individuals to GSDs, we expect these districts to also engage actively in recruiting teachers. While we understand that websites are not the only way to recruit teachers, they are the primary way an individual from outside the area may become familiar with a district prior to applying for a position. To ascertain the Arkansas districts' relative use of materialistic and non-materialistic recruitment incentives, we explored the websites of all of 53 districts labeled as a GSD by the Arkansas Department of Education.

Arkansas is also home to two KIPP (Knowledge is Power Program) non-profit charter schools. As part of the 99 campus KIPP national network, the two KIPP sites in Arkansas represent two of the three rural KIPP locations nationally. (KIPP typically locates in large cities.) KIPP Delta is listed as a geographic shortage district by the Arkansas Department of Education. Yet KIPP Delta campuses typically have an average of 14 applicants for each teaching position advertised, a number greater than for the geographic shortage district vacancies. We compared the contents of the 53 district GSD websites to KIPP Delta.

Using a prior study comparing public school websites nationally (Shuls \& Maranto, forthcoming), we identified two monetary incentives, salary and benefits, along with six non-monetary incentives or school characteristics that might be used to encourage teachers to apply:

- opportunity to engage in public service

- freedom and autonomy in the classroom

- opportunities for advancement

- focus on professional growth

- collegial environment focused on teamwork

- results-driven organization

While not exhaustive, this is a representative list of the material and non-material incentives that may be used to attract teacher applicants. We used strict selection criteria to determine if a website would be coded as displaying each of the six types of incentives.

Upon visiting the website of each district we looked for the page that was used for teacher recruitment. Often this page was indicated by the words: Teach here, careers, or human resources. From the main teacher recruitment page, we looked for the criteria on teacher recruitment pages that could be easily reached within two mouse clicks. Some of the information we sought may have been displayed on other parts of the website that we did not explore; however, we were examining information that was easily accessible to prospective teachers from the main teacher recruitment webpage. Below is a detailed explanation of the selection criteria we used for each of the non-monetary and monetary incentives. Three coders used a binary coding system to code these incentives.

\section{Selection Criteria}

The eight website selection criteria used included public service, freedom, advancement, professional growth, teamwork, results-driven, salary and benefits.

Public service. A website was coded as appealing to public service motives if it seemed to appeal to a teacher's sense of duty. We included websites that mentioned closing the achievement gap, doing whatever it takes, and difficult or challenging workloads.

Freedom. A website was coded as appealing to a teacher's sense of freedom if it offered teachers the ability to innovate in the classroom. When specific words were used for the type of applicants desired we coded this as appealing to a sense of freedom. These key words included: innovative, entrepreneurial, and creative.

Advancement. A website was coded as appealing to opportunities for advancement if it described possibilities of rising to leadership roles. Leadership roles were defined as anything from grade level chairs, master teachers, and future principals or school leaders.

Professional growth. A website was coded as appealing to professional growth motives if it mentioned opportunities to grow as a teacher. These opportunities to grow included professional development, mentoring, feedback from teachers or principals. 
Teamwork. A website was coded as appealing to teamwork motives if it described the environment as a team environment. We accepted phrases such as 'join our team' as fulfilling the teamwork criteria. We also accepted collaboration and family as key words for this construct.

Results driven. A website was coded as appealing to results driven individuals if it described the environment as being focused on results or student achievement. We also accepted the following key words as signals: data-driven and results-driven.

Salary. A website was coded as displaying salary if it displayed a salary schedule or made reference to pay.
Benefits. Websites that listed specific benefits or alluded to benefits, including healthcare or retirement, were coded as expressing this incentive.

We used this scheme to compare all 53 Arkansas school districts that were listed as geographic shortage districts in 2010 by the Arkansas Department of Education (ADE, 2010).

\section{Results}

As a whole, the GSD district websites displayed very little information relevant to recruiting new teachers. The percentage of the 53 traditional public school districts displaying the eight criteria is presented in Table 3.

Table 3

Recruitment Incentives Displayed on GSD Websites

\begin{tabular}{lc}
\hline \multicolumn{1}{c}{ Construct } & $\begin{array}{c}\text { Percent of Websites Displaying } \\
\text { Info. }\end{array}$ \\
\hline Salary & $26 \%$ \\
Benefits & $7 \%$ \\
Teamwork & $4 \%$ \\
Professional Growth & $0 \%$ \\
Public Service & $0 \%$ \\
Innovate & $0 \%$ \\
Results Driven & $0 \%$ \\
Advancement & $0 \%$ \\
\hline
\end{tabular}

Note: There were actually 54 GSD districts on the list in 2010, but since then the Twin Rivers School District has been dissolved into two other districts and no longer exists.

The only district to consistently utilize its website for the recruitment of teachers was the KIPP Delta. The three coders agreed that KIPP Delta's website was superior to other school websites in the sample. It was appealing and eye catching. It displayed pictures of students and provided useful information to prospective teachers. Additionally, it had information that appealed to both material and non-material interests. The following is an excerpt from the KIPP Delta careers page:

Whether you are interested in teaching in the classroom or supporting our schools through the central office, your work will directly impact the lives of hundreds of children in the Delta. KIPP Delta offers meaningful professional development and ample opportunities to develop your leadership skills. We encourage staff members to wear multiple hats so that you can develop relationships and grow in areas outside of your main job role. If you are looking for a place where you can grow as a professional and truly make a difference, KIPP Delta may be a perfect fit!
There was more information in this one paragraph about teaching at KIPP than in the combined total of all 53 GSD websites. If the GSDs are in need of teachers, it is hard to tell from the recruitment information on their websites. Of all 53 GSD districts, not one appealed to applicants' desire for advancement, freedom, professional growth, or a focus on results, and only two mentioned team and one public service. Information about teaching jobs was often hard to find. In fact, we were unable to find any information at all regarding employment on ten district websites. Of the 43 districts that did have information about employment, most only had a job application page. In comparison, KIPP Delta appealed to every non-monetary construct except for freedom.

On the surface, the GSDs did seem more likely to appeal to monetary motives. Eleven districts' salary schedules were easily accessible from their main employment webpage. This finding, however, does not tell the whole story. Arkansas requires all traditional public school districts to display their salary schedule somewhere on the webpage. Undoubtedly, the salary schedules were displayed in 
various other places on each of these websites, just not on a job employment page. In short, the GSD websites simply did not provide much useful information to prospective teachers. GSD websites seem woefully inadequate at appealing to nonmonetary or monetary incentives of prospective teachers. Such failure to systematically provide information specific to recruiting teachers typifies even large districts that have trouble attracting teachers (Hess, 2010).

While rural school districts in Arkansas typically report difficulties in recruiting teachers, the two rural Knowledge Is Power Program (KIPP) sites in the state report having roughly 14 applicants for each open position. This may be partly because they provide a plethora of information for prospective teachers on their websites. KIPP Delta is surrounded by GSD's. Generally, whether in Mississippi, Arkansas, or Tennessee, the Mississippi Delta is one of the most economically disadvantaged locations in the United States and one of the hardest in which to place quality teachers. Yet KIPP manages to attract highly qualified applicants and has considerable success in retaining them. KIPP Delta has been hailed as one of the best schools in Arkansas (Maranto \& Shuls, 2011). Our estimates suggest KIPP Delta is in the top $2 \%$ of Arkansas schools in regards to valueadded student achievement. Of the 11 AfricanAmerican students who passed the AP calculus exam in the entire state of Arkansas in 2010, three were KIPP Delta students.

\section{Conclusion}

In nearly every state, some schools are hard to staff because of geographic teacher shortages. To staff such schools, policy-makers often turn to monetary incentives because they are controllable, and indeed this explains part of the current push toward merit pay (Ritter et al., 2009). Unfortunately, particularly in the realm of education policy, the impacts of material incentives at the school and school district level are not always predictable (Hanushek \& Lindseth, 2009).

Some believe the way to attract teachers to high needs areas is to pay teachers more money. Yet the costs might be substantial. In northwest Arkansas, which has grown rapidly in part because of the University of Arkansas at Fayetteville and because of Wal-Mart headquarters in Bentonville, teachers can easily make $\$ 15,000$ more than in a GSD. They can also live in a growing and more urbanized environment offering more cultural amenities and social opportunities, albeit with much more traffic and far higher housing costs. Generally, a $\$ 3,000$ or $\$ 4,000$ incentive seems woefully insufficient to attract the highest quality teachers to GSDs, given the alternatives. If the incentive was increased to $\$ 15,000$ more teachers may apply, but what would happen to teachers already teaching in the GSD? Would the incentive also be available for them? If so, such state funded pay raises would not be politically sustainable. If not, these teachers might be incentivized to move to another GSD nearby to receive the incentive. Further, there is at least some reason to think that emphasizing monetary incentives could ultimately undermine the public service ethic of the teaching profession, leading to less focus on the long-term wellbeing of children (Maranto \& Maranto, 2006). In short, schools are about more than just money, and the evidence presented suggests that the monetary incentives employed by the Arkansas Department of Education have been insufficient and insufficiently targeted to significantly assist GSD's in teacher recruitment and retention.

Notably, rural school districts may face certain distinct challenges compared to charter schools. Freed from certain state regulations, charter schools may have more ability to adjust to local conditions (Wenger, Dinsmore, \& Villagomez, 2012). KIPP, in particular, is a network with a national reputation. In contrast, few teachers have heard of the Piggot, Dumas, or Marked Tree Public school districts, to name but a few rural districts in Arkansas. A national "brand" gives KIPP Delta a recruiting edge. Moreover, traditional public schools are required to hire certified teachers, an expectation that may disproportionately hinder rural schools (Eppley, 2009). KIPP Delta can hire uncertified teachers, though they must be highly qualified. Previous research suggests that hiring uncertified teachers does not necessarily harm student achievement (Maranto \& McShane, 2012). Yet KIPP has recruitment disadvantages as well. KIPP teachers are required to work longer hours and more days, with little more pay. Some argue KIPP Delta teachers are held to higher standards, making the job more demanding. Furthermore, KIPP Delta teachers have at-will contracts.

From the findings of this study, we make the following recommendations for recruiting in rural geographic shortage areas.

\section{Have a Place for Teacher Recruitment on the District's Webpage}

Improving the format and increasing recruitment information on GSD websites may enhance the recruitment of high quality teachers. Understandably, small districts may lack the talent to develop a sophisticated website. Often small rural schools have students create and maintain the website as part of a 
technology class. Even though these schools may not have the ability to create an amazing website, they do have the ability to type some text on a page. This may be an area in which the SEA can offer important support. If schools do not have the ability to create a high quality webpage, the state could provide assistance. Arkansas provided over 1.5 million dollars in loan forgiveness for teachers in subject or geographic shortage areas in 2010 . One option may be to divert $\$ 50,000$ of these funds to provide technological support to all geographic shortage districts. After a one-time grant to upgrade the websites, funding could be reduced to that needed for periodic upgrades. Alternatively, the money could provide professional development for a number of years until the schools are able to take on web design responsibilities themselves. It may not be true to say of school web pages, "if you build it they will come," but certainly if a prospective teacher cannot find any information on your web page they probably will not apply.

\section{Sell Your Schools to Potential Applicants}

It is not enough to simply have an application or the salary schedule posted on a webpage. School districts should use their webpage to sell their school to potential applicants. This should be a place to highlight the unique things about a school. Time and time again on the various KIPP web pages information was presented to attract teachers. KIPP serves disadvantaged students, and uses public service appeals to attract teachers. Most GSDs in Arkansas also serve disadvantaged students and they could easily make such appeals. They could also highlight small town environments, low housing costs, outdoor recreation, scenery, or other potentially attractive aspects of the school or community.

\section{References}

Anderson, R., \& Chang, B. (2011). Mathematics course-taking in rural high schools. Journal of Research in Rural Education, 26(1).

Arkansas Department of Education. (2008). Arkansas' Equity Plan: Updated October 2008. Retrieved February 10, 2013, from http://arkansased.org/nclb/pdf/equity_plan_1008. pdf

Arkansas Department of Higher Education. (2010). State teacher education program: Shortage area list. Retrieved from http://www.adhe.edu/SiteCollectionDocuments/F inancial\%20Aid\%20Division/State\%20Teacher $\%$ 20Education \%20Program/STEP\%20Shortage $\% 20$ Areas.pdf

Ballou, D., \& Podgursky, M. (1997) Teacher pay and teacher quality. Kalamazoo, MI: W. E. Upjohn Institute for Employment Research.

Chetty, R., Friedman, J. N., \& Rockoff, J. E. (2011). The long-term impacts of teachers: Teacher value-added and student outcomes in adulthood. National Bureau of Economic Research. Working paper 17699. Retrieved from http://www.nber.org/papers/w17699

Clotfelter, C., Glennie, E., Ladd, H., \& Vigdor, J. (2006). Would higher salaries keep teachers in high-poverty schools? Evidence from a policy intervention in North Carolina. National Bureau of Economic Research Working Paper Series. Retrieved from http://www.nber.org/papers/w12285
Eppley, K. (2009). Rural schools and the highly qualified teacher provision of No Child Left Behind: A critical policy analysis. Journal of Research in Rural Education, 24(4).

Grissom, J. A. (2008). But do they stay? Addressing issues of teacher retention through alternative certification. In P. Grossman \& S. Loeb (Eds.), Alternative routes to teaching (pp. 129-158). Cambridge, MA: Harvard Education Press.

Hanushek, E., \& Lindseth, A. (2009). Schoolhouses, courthouses, and statehouses: Solving the funding-achievement puzzle in America's public schools. Princeton: Princeton University Press.

Hanushek, E., Kain, J. F., O’Brien, D., Rivkin, S. G. (2005). The market for teacher quality. Stanford, CA: Stanford University.

Hanushek, E. A., Kain, J. F., \& Rivkin, S. G. (1999). Do higher salaries buy better teachers? National Bureau of Economic Research. Working paper 7082. Retrieved from http://nber.org/papers/w7082

Hanushek, E. A., Kain, J. F., \& Rivkin, S. G. (2004). Why public schools lose teachers. Journal of Human Resources, 39(2), 326-354.

Hess, F. M. (2010). Education unbound. Arlington: ASCD

Ingersoll, R. M. (2002). The teacher shortage: A case of wrong diagnosis and wrong prescription. National Association of Secondary School Principals Bulletin, 86(631), 16-31.

Ingersoll, R. M. (2003). Is there really a teacher shortage? Seattle, WA: Center for the Study of 
Teaching and Policy: University of Washington. Retrieved from http://depts.washington.edu/ctpmail/PDFs/Shorta ge-RI-09-2003.pdf

Liu, E., Johnson, S., \& Peske, H. G. (2004). New teachers and the Massachusetts signing bonus: The limits of inducements. Educational Evaluation and Policy Analysis, 26(3), 217-236.

Maranto, R., \& Maranto, A. (2006). Markets, bureaucracies, and clans: The role of organization culture. In F. Hess (Ed.) Educational entrepreneurship: Realities, Challenges, Possibilities. Cambridge, MA: Harvard Education Press.

Maranto, R. \& McShane, M. Q. (2012). President Obama and education reform: The personal and the political. New York: Macmillan/Palgrave.

Maranto, R., \& Shuls, J. V. (2011). Lessons from KIPP Delta. Phi Delta Kappan, 93(3), 52-56.

McClure, C. \& Reeves, C. (2004). Rural teacher recruitment and retention: Review of the research and practice literature. Nashville, TN. Appalachia Educational Laboratory.

Payne, C. M. (2008). So much reform, so little change. Cambridge, MA: Harvard Education Press.
Rivkin, S., Hanushek, E. \& Kain, J. (2005). Teachers, schools and academic achievement. Econometrica, 73(2), 418-58.

Ritter, G. W. (2009). Education reform in Arkansas: Hitting a moving target. In J.A. Parry, \& R.P. Wang, (Eds.), Readings in Arkansas politics and government (pp. 385-404). Fayetteville, AR: University of Arkansas Press.

Ritter, G. W., Maranto, R., \& Buck, S. (2009). Harnessing private incentives in public education. Review of Public Personnel Administration, 29(3), 249-269.

Shuls, J. V., \& Maranto, R. (forthcoming). Show them the mission: A comparison of teacher recruitment incentives in high need communities. Social Science Quarterly.

Steele, J. L., Murnane, R. J., \& Willett, J. B. (2009). Do financial incentives help low-performing schools attract and keep academically talented teachers? Evidence from California. National Bureau of Economic Research. Working paper 14780. Retrieved from http://www.nber.org/papers/w14780

\begin{abstract}
About the Authors:
Robert Maranto (rmaranto@uark.edu) is the $21^{\text {st }}$ Century Chair in Leadership in the Department of Education Reform at the University of Arkansas. He recently co-authored (with Michael McShane) President Obama and education reform: The personal and the political.
\end{abstract}

James V. Shuls (james.shuls@ @ showmeinstitute.org) is the education policy analyst at the Show-Me Institute in Missouri and a doctoral candidate in education policy at the University of Arkansas. 